\title{
Pengaruh Kombinasi Buah Jeruk Nipis dan Buah Mengkudu Terhadap Mortalitas Pediculus humanus capitis
}

\author{
Fitria Diniah Janah Sayekti, Muhammad Taufiq Qurrohman, Damar Ajeng \\ Priyandari, Chris Srikandini \\ Sekolah Tinggi Ilmu Kesehatan Nasional
}

*Correspondence adress: fitria.diniah@stikesnas.ac.id

\section{㟔㽞}

ISSN: 1979-4703 (p)

ISSN: 2527-9726 (e)

Keywords:

Jeruk nipis, Mengkudu, Pediculosis capitis

\section{A B S T R A C T}

Head lice (Pediculus humanus capitis) greatly interferes with human activity because it can cause itching of the head, redness and severe infections. The use of natural insecticides is recommended, because natural insecticides are considered safer. Potential anti lice plants are lime and noni. The combination of the two is believed to have a more effective effect on head lice mortality. This study aims to study and determine the effect of a combination of lime juice and noni on the mortality of Pediculus bumanus capitis. The concentration of lime and noni which are used are 25\%, 50\%, 75\% and 100\%, respectively. The combination of test materials used was 25\% limes $75 \%$ noni; $50 \%$ lime $50 \%$ noni; $75 \%$ lime and 25\% noni, negative control and positive control. The combination of the extract of noni and lime juice had the highest mortality effect on Pediculus humanus capitis with a concentration of $25 \%$ combination of lime; $75 \%$ noni.

\section{A B S T R A K}

Kutu rambut (Pediculus humanus capitis) sangat mengganggu aktivitas manusia karena dapat menyebabkan gatal pada kepala, kemerahan dan infeksi berat. Penggunaan insektisida alami lebih dianjurkan, karena insektisida alami dinilai lebih aman. Tanaman yang berpotensi sebagai antikutu adalah jeruk nipis dan mengkudu. Kombinasi keduanya diyakini akan memberikan efek yang lebih efektif terhadap mortalitas kutu rambut. Penelitian ini bertujuan mempelajari dan mengetahui pengaruh kombinasi perasan jeruk nipis dan mengkudu terhadap mortalitas Pediculus humanus capitis. Konsentrasi jeruk nipis dan mengkudu yang digunakan masing-masing adalah $25 \%, 50 \%, 75 \%$ dan $100 \%$. Kombinasi bahan uji yang digunakan adalah $25 \%$ jeruk nipis $75 \%$ mengkudu; $50 \%$ jeruk nipis 50\% mengkudu; $75 \%$ jeruk nipis dan 25\% mengkudu, kontrol negatif dan kontrol positif. Kombinasi ekstrak perasan buah mengkudu dan jeruk nipis memiliki efek mortalitas paling tinggi terhadap Pediculus humanus capitis dengan konsentrasi kombinasi 25\% jeruk nipis; $75 \%$ mengkudu. 


\section{Pendahuluan}

Kutu rambut (Pediculus bumanus capitis) merupakan parasit yang menginvasi kulit kepala manusia. Kutu rambut hidup dengan menghisap darah manusia dan dapat menyebabkan lesi pada kulit. Kutu rambut sangat mengganggu aktivitas manusia karena dapat menyebabkan gatal pada kepala, kemerahan dan infeksi berat. Invasi kutu rambut menyebabkan helaian rambut akan melekat satu sama lainnya dan mengalami pengerasan, serta ditemukan adanya eksudat nanah akibat dari peradangan gigitan parasit tersebut (Ansyah, 2013).

Prevalensi kutu rambut di beberapa negara di dunia masih cukup tinggi. Prevalensi anak SD di Yordania yang menderita Pediculosis capitis sebesar 26,6\%, di India 28,3\%, Melayu 18,9\%, dan Cina 4,6\%. Infeksi kutu rambut di Bangkok Timur lebih banyak terjadi pada anak perempuan sekitar 47,12\% dibandingkan dengan anak laki-laki (Albashtawy dan Hasna, 2012). Penderita kutu rambut biasanya anak-anak pra-sekolah, akan tetapi usia remaja juga memungkinkan terjangkit kutu rambut. Anak-anak dibawah usia 15 tahun, kurang mampu menjaga kebersihan dirinya secara mandiri. Remaja di atas usia 15 tahun memiliki kemungkinan terjangkit kutu rambut karena belum mengetahui bahaya yang diakibatkan oleh kutu rambut (Fadilah, 2015).

Efek yang dapat ditimbulkan akibat kutu rambut yaitu rasa gatal yang hebat dan menjadi pemicu alergi. Rasa gatal seringkali tidak tertahankan, sehingga garukan yang terlalu kuat menyebabkan kulit kepala lecet dan iritasi. Luka lecet dan iritasi ini dapat menimbulkan terjadinya infeksi yang parah, seperti menyebabkan koreng. Pada anak yang terinfeksi kutu rambut dewasa sekitar 30 ekor dapat kehilangan darah sekitar 0,008 $\mathrm{ml}$ per hari, hal tersebut dapat menyebabkan kekurangan zat besi dan anemia (Nindia, 2016).

Cara yang digunakan untuk mengatasi kutu rambut yaitu secara farmakologis dan non farmakologis. Secara non farmakologis, penghilangan kutu rambut dapat dilakukan dengan menggunakan sisir kutu sampai mencukur habis rambut (cukur gundul). Penghilangan kutu rambut secara farmakologis dapat menggunakan insektisida. Penggunaan insektisida yang tidak terkontrol bisa menyebabkan kutu rambut menjadi resisten terhadap insektisida tersebut (Rahayu, 2016).

Insektisida alami merupakan bahan aktif yang berasal dari tumbuhan, relatif mudah dibuat dan tidak menimbulkan dampak negatif bagi manusia maupun lingkungan sekitarnya. Tanaman yang memiliki potensi sebagai insektisida alami yaitu mengkudu dan jeruk nipis (Citrus aurantifolia). Jeruk nipis mengandung senyawa saponin, flavonoid, dan limonoida. Senyawa yang terkandung didalam daun mengkudu salah satunya yaitu flavonoid. Flavonoid bertindak sebagai stomach poisoning atau racun perut, sehingga apabila flavonoid masuk ke dalam tubuh serangga maka sistem pencernaannya akan terganggu. Senyawa tersebut mampu menghambat reseptor perasa pada daerah mulut serangga, sehingga menyebabkan serangga tidak mampu mengenali makanannya, hingga mati kelaparan (Darmadi, 2018). Senyawa limonoida berfungsi sebagai racun pada serangga dan masuk kedalam tubuh serangga dengan berbagai cara. sebagai racun perut, menyebar 
ke jaringan saraf dan melalui kulit tubuh serangga yang bersifat permeable serta dengan cara fumigant, yaitu dengan cara melalui pernafasan serangga.

Penggunaan insektisida alami lebih dianjurkan, karena insektisida alami dinilai lebih aman. Struktur senyawa pada insektisida alami lebih mudah terurai sehingga tidak mengalami akumulasi serta memiliki kemungkinan yang lebih kecil dalam menyebabkan iritasi (Amalia, 2016). Berdasarkan latar belakang diatas, kemampuan kombinasi perasan mengkudu dan jeruk nipis terhadap mortalitas Pediculus bumanus capitis penting untuk dilakukan.

\section{Metode Penelitian}

\section{Pembuatan Sari Jeruk Nipis dan Mengkudu}

Pembuatan sari jeruk nipis dan mengkudu dilakukan di Laboratorium STIKES Nasional dengan metode perasan menggunakan pelarut aquades. Masing-masing sampel disortasi (dipilih yang yang bagus, berwarna putih transparan, segar, dan matang) kemudian dilakukan pencucian sampel sampel bersih dari kotoran dan tanah. Buah jeruk nipis dan mengkudu ditimbang sebanyak $1 \mathrm{Kg}$ dipotong beberapa bagian kemudian dihaluskan menggunakan blender. Buah jeruk nipis dan mengkudu yang telah blender diletakkan di kain saring kemudian diperas sampai keluar sari buahnya. Sari buah dimasukan kedalam gelas beker. Pada proses ini sari buah memiliki konsentrasi 100\%. Sari buah yang diperoleh diencerkan dengan aquades untuk konsentrasi 25\%, 50\%,75\%. Hasil yang diperoleh digunakan untuk uji mortalitas terhadap Pediculus bumanus capitis.

\section{Pembuatan Kombinasi Sari Jeruk Nipis dan Mengkudu}

Sari buah jeruk nipis dan mengkudu yang memiliki konsentrasi 100\% dikombinasikan satu sama lain dengan kombinasi konsentrasi yaitu :

a. $25 \%$ jeruk nipis dan $75 \%$ mengkudu

b. $50 \%$ jeruk nipis dan $50 \%$ mengkudu

c. $75 \%$ jeruk nipis dan $25 \%$ mengkudu

Kombinasi konsentrasi digunakan untuk uji mortalitas terhadap Pediculus bumanus capitis.

\section{Uji Mortalitas Pediculus humanus capitis}

Pediculus humanus capitis yang digunakan memiliki kriteria bentuk dewasa berukuran 1-3 mm, warna coklatan-kehitaman, sehat (aktif bergerak). Percobaan dilakukan dengan menggunakan cawan petri dan millimeter blok. Masing-masing larutan uji dimasukkan kedalam cawan petri sebanyak $1,5 \mathrm{ml}$ dan dipastikan tersebar secara merata. Kertas millimeter blok dimasukkan pada cawan petri dengan mengikuti pola bentuk cawan petri hingga larutan uji merata pada permukaan kertas. Sampel kutu rambut dimasukkan sebanyak empat ekor kedalam masing-masing cawan petri. Cawan petri yang berisi kontrol negatif menggunakan aquades dan dilakukan prosedur seperti diatas. Cawan petri 


\section{At-Taqaddum}

Vol. 12 No. 1 (2020) 47-54

yang berisi kontrol positif menggunakan permethrin 1\% dan dilakukan prosedur seperti diatas. Pengamatan dan perhitungan dilakukan terhadap Pediculus bumanus capitis yang mati pada setiap perlakuan dalam 5, 10, 15, 20, 25, 30, 35, 40, 45, 50, 55, dan 60 menit setelah Pediculus humanus capitis diberi larutan uji.

\section{Uji Fitokimia Perasan Buah Mengkudu (Morinda citrifolia)}

a. Uji Flavonoid

Beberapa tetes lapisan air ekstrak buah mengkudu dimasukkan tabung reaksi lalu tambahkan $1-2$ butir logam magnesium dan beberapa tetes asam klorida pekat. Senyawa flavonoid ditandai dengan terbentuknya warna jingga, merah muda sampai merah.

b. Uji Saponin

Lapisan air ekstrak buah mengkudu dimasukkan kedalam tabung reaksi lalu dikocok. Apabila terbentuk busa yang bertahan selama 5 menit, menandakan positif adanya saponin.

c. Uji Tanin

Lapisan air ekstrak buah mengkudu sebanyak 5 tetes ditambahkan dengan $1 \mathrm{~mL}$ larutan $\mathrm{FeCl} 3$ 10\%. Jika terbentuk warna biru tua, biru kehitaman atau hitam kehijauan menunjukkan adanya senyawa polifenol dan tanin.

\section{Analisa Data}

Dalam setiap 5 menit selama 120 menit dicatat waktu kematian Pediculus bumanus capitis. Kriteria kematian kutu kepala didefinisikan sebagai tidak adanya gerakan anggota badan maupun antena. Data tersebut kemudian diolah menggunakan analisa statistik Kruskal-wallis

\section{Hasil dan Pembahasan}

Pengaruh kombinasi ekstrak perasan buah mengkudu dan jeruk nipis sebagai insektisida dilakukan dengan melakukan uji mortalitas terhadap Pediculus humanus capitis. Uji mortalitas dilakukan dengan cara menempatkan Pediculus bumanus capitis pada cawan petri yang berisi berbagai konsentrasi, kontrol negatif dan kontrol positif dengan lama waktu pengamatan 120 menit dan diamati setiap 5 menit. Mortalitas Pediculus bumanus capitis merupakan waktu kematian Pediculus bumanus capitis yang mati setelah diberi perlakuan dengan berbagai konsentrasi ekstrak perasan buah mengkudu, jeruk nipis dan kombinasi diantara keduanya. Mortalitas ini dapat dilihat dari tidak adanya pergerakan dari anggota tubuh Pediculus bumanus capitis. Semakin singkat waktu kematian kutu kepala menunjukan semakin kuat larutan uji dalam menyebabkan mortalitas. Pengaruh kombinasi ekstrak perasan buah mengkudu dan jeruk nipis terhadap mortalitas Pediculus bumanus capitis dapat dilihat pada gambar 1 . 


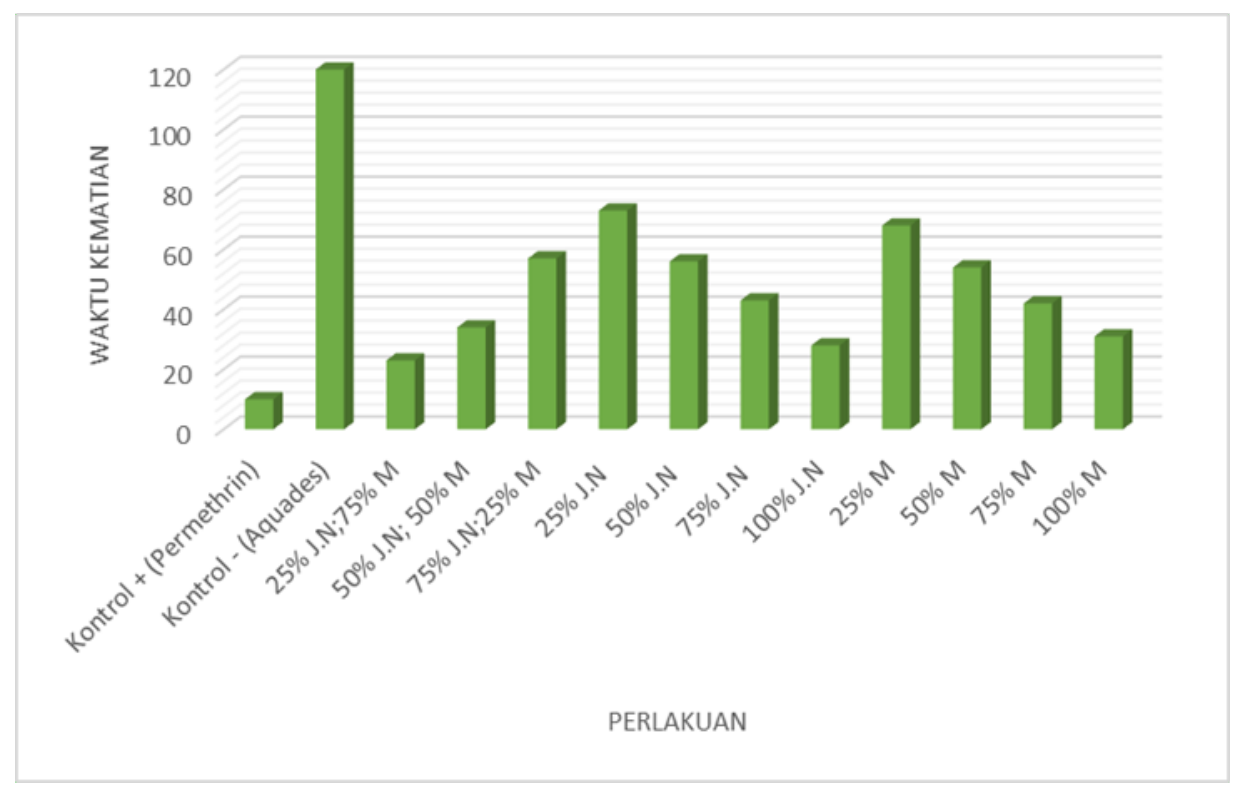

\section{Gambar 1. Waktu kematian Pediculus humanus capitis pada berbagai perlakuan Keterangan : J.N (Jeruk Nipis); M (Mengkudu)}

Gambar 1 menunjukan bahwa semakin tinggi konsentrasi pada ekstrak perasan tunggal maka semakin cepat waktu kematian Pediculus humanus capitis. Pada ekstrak kombinasi menunjukkan bahwa ekstrak yang menyebabkan waktu kematian paling cepat adalah kombinasi $25 \%$ jeruk nipis; $75 \%$ mengkudu. Kombinasi tersebut menunjukkan mortalitas paling tinggi ditandai dengan waktu kematian paling cepat dibandingkan ekstrak tunggal lainnya

\begin{tabular}{|c|c|c|c|c|c|c|c|c|c|}
\hline \multicolumn{10}{|c|}{ waktu_kematian } \\
\hline & \multirow[t]{2}{*}{ Konsentrasi } & \multirow[t]{2}{*}{$\mathrm{N}$} & \multicolumn{7}{|c|}{ Subset for alpha $=0.05$} \\
\hline & & & 1 & 2 & 3 & 4 & 5 & 6 & 7 \\
\hline \multirow{14}{*}{ Tukey HSD ${ }^{a}$} & Kontrol (+) Permethrin 1\% & 8 & 10.00 & & & & & & \\
\hline & $75 \%$ buah $\mathrm{M}+25 \%$ buah JN & 8 & & 23.13 & & & & & \\
\hline & Perasan jeruk nipis $100 \%$ & 8 & & 28.13 & 28.13 & & & & \\
\hline & Perasan buah mengkudu $100 \%$ & 8 & & 31.25 & 31.25 & & & & \\
\hline & $50 \%$ buah $\mathrm{M}+50 \%$ buah JN & 8 & & & 34.38 & 34.38 & & & \\
\hline & Perasan buah mengkudu $75 \%$ & 8 & & & & 41.88 & & & \\
\hline & Perasan jeruk nipis $75 \%$ & 8 & & & & 42.50 & & & \\
\hline & Perasan buah mengkudu $50 \%$ & 8 & & & & & 54.38 & & \\
\hline & Perasan jeruk nipis $50 \%$ & 8 & & & & & 55.63 & & \\
\hline & $25 \%$ buah $\mathrm{M}+75 \%$ buah JN & 8 & & & & & 56.88 & & \\
\hline & Perasan buah mengkudu $25 \%$ & 8 & & & & & & 67.50 & \\
\hline & Perasan jeruk nipis $25 \%$ & 8 & & & & & & 72.50 & \\
\hline & Kontrol (-) Aquades & 8 & & & & & & & 120.00 \\
\hline & Sig. & & 1.000 & .052 & .321 & .052 & .998 & .673 & 1.000 \\
\hline $\begin{array}{l}\text { Means for gr } \\
\text { a. Uses Harn }\end{array}$ & $\begin{array}{l}\text { Jups in homogeneous subsets are } \\
\text { tonic Mean Sample Size }=8.000 \text {. }\end{array}$ & isplay & & & & & & & \\
\hline
\end{tabular}

Gambar 2. Distribusi Homogenous Subset 
Berdasarkan hasil uji statistik dapat diketahui bahwa perlakuan pada berbagai varisasi konsentrasi belum mampu menyamai waktu kematian kontrol postif menggunakan permethrin. Variasi konsentrasi yang mendekati efektifitas dari kontrol positif adalah kombinasi $75 \%$ buah mengkudu dan $25 \%$ buah jeruk nipis, perasan jeruk nipis $100 \%$ perasan buah mengkudu $100 \%$.

Pada kontrol negatif pelarut yang digunakan adalah aquades. Kontrol negatif menggunakan aquades tidak memberikan efek mortalitas terhadap Pediculus bumanus capitis. Aquades merupakan suatu jenis air murni yang telah dilakukan destilasi pada temperatur titik didihnya. Aquades tidak memiliki kandungan senyawa yang dapat membahayakan apabila digunakan. Kontrol positif dalam penelitian menggunakan permetrin 1\%. Permetrin dapat menjadi neurotoxin pada serangga. Perlakuan dengan permetrin $1 \%$ menunjukan efek mortalitas yang lebih kuat daripada ekstrak pada semua konsentrasi (Ningsih, 2014). Mortalitas Pediculus bumanus capitis disebabkan karena adanya senyawa fitokimia yang terkandung dalam ekstrak perasan buah mengkudu dan jeruk nipis. Pada hasil uji fitokimia perasan buah mengkudu positif mengandung senyawa fitokimia saponin, flavonoid dan tanin. Jeruk nipis (citrus aurontifolia) mengandung senyawa fitokimia diantaranya: flavonoid, saponin, tannin, dan alkaloid.

Saponin diketahui mempunyai efek anti serangga karena saponin yang terdapat pada makanan yang dikonsumsi serangga dapat menurunkan aktivitas enzim pencernaan dan penyerapan makanan (Amalia, 2016). Flavonoid merupakan senyawa pertahanan tumbuhan yang dapat bersifat menghambat makan serangga dan juga bersifat toksik. Flavonoid bekerja sebagai inhibitor kuat pernapasan atau sebagai racun pernapasan. Flavonoid mempunyai cara kerja yaitu dengan masuk ke dalam tubuh serangga melalui sistem pernapasan yang kemudian akan menimbulkan kelayuan pada syaraf serta kerusakan pada sistem pernapasan dan mengakibatkan serangga tidak bisa bernapas dan akhirnya mati (Amalia, 2016)

Tanin dapat menurunkan kemampuan mencerna makanan dengan cara menurunkan aktivitas enzim pencernaan (protease dan amilase) serta mengganggu aktivitas protein usus. Serangga yang memakan tumbuhan dengan kandungan tanin tinggi akan memperoleh sedikit makanan, akibatnya akan terjadi penurunan pertumbuhan (Dinata, 2009). Alkaloid merupakan racun perut bagi serangga, serta tannin dan saponin yang juga merupakan senyawa dari jeruk nipis akan masuk kedalam tubuh serangga kemudian menghambat enzim pencernaan pada kutu rambut sehingga metabolisme akan terganggu dan menimbulkan kematian (Rachman,2015).

Faktor-faktor yang mempengaruhi status kerentanan beberapa serangga, yaitu : faktor genetik yaitu berupa gen-gen yang menjadi pembentukan enzim esterase, yang dapat menyebabkan resistensi serangga terhadap insektisida baik organofosfat atau piretroid. Faktor biologis yaitu adanya pergantian generasi, dan waktu berakhirnya perkembangan setiap generasi pada serangga di. Faktor operasional meliputi bahan kimia yang digunakan dalam pengendalian vektor serta aplikasi insektisida tersebut di lapangan (Pradani, 2018). 


\section{Kesimpulan}

Kombinasi ekstrak perasan buah mengkudu dan jeruk nipis memiliki efek mortalitas paling tinggi terhadap Pediculus humanus capitis dengan konsentrasi kombinasi $25 \%$ jeruk nipis; $75 \%$ mengkudu. Variasi konsentrasi kombinasi dan senyawa khusus yang berperan menyebabkan mortalitas pada Pediculus humanus capitis perlu diteliti lebih lanjut. Efek histopatologi Pediculus bumanus capitis setelah perlakuan ekstrak juga perlu untuk dianalisa lebih lanjut.

\section{Daftar Pustaka}

Albashtawy and Husna. (2012). Pediculosis capitis among primary-school children in Mafraq covernorate. Jordan : 43-47.

Amalia, R. (2016). Daya Bunuh Air Perasan Daun Mengkudu (Morinda citrifolia L.) Terhadap Kematian Larva Aedes aegypti. Skeripsi. Jurusan Ilmu Kesehatan Masyarakat Fakultas Ilmu Keolahragaan Universitas Negeri Semarang

Ansyah, A. (2013). Hubungan Personal Hygiene Dengan Angka Kejadian Pediculosis capitis Pada Santri Putri Pondok Pesantren Modern Islam Assalaam Surakarta. Skripsi. Surakarta: Universitas Muhammdadiyah Surakarta.

Darmadi. (2018). Efektifitas Ekstrak Kulit Duku (Lansium domesticum corr) Terhadap Mortalitas Pedikulus bumanus capitis Sebagai Penyebab Pedikulosis Pada Anak. Akademi Analis Kesehatan Yayasan Fajar Pekanbaru : Universitas Abdurrab Pekanbaru

Dinata, Arda. 2009. Basmi Lalat dengan Jeruk Manis. Ciamis: Litbang Pemberantasan Penyakit Bersumber Binatang. Balitbang Kesehatan Depkes RI.

Fadilah, H. (2015). Perbedaan Metode Ceramah Dan Leaflet Terhadap Skor Pengetahuan Santriwati Tentang Pedikulosis kapitis Di Pondok Pesantren Al Mimbar Sambongdukuh Jombang. Skripsi. Jakarta: Universitas Negeri Syarif hidayatullah Jakarta.

Nindia, Y. (2016). Prevalensi Infestasi Kutu Kepala (Pediculus humanus capitis) Dan Faktor Risiko Penularannya Pada Anak Sekolah Dasar Di Kota Sabang Provinsi Aceh. Tesis. Bogor: Institut Pertanian Bogor.

Ningsih , Y.S. (2014). Pengaruh Penambahan Aquadestdan Air Accu (H2SO4 30\%) Terhadap Arus dan Tegangan dari Sel Accu Dengan Menggunakan Air Singkong Karet (Manihot Glaziovii. M.A). Sumatra Barat. Universitas Negeri Padang. Journal Pilar Of Physic. Vol 1

Pradani, Firda Yanuar. (2018). Efikasi Insektisida Gokilath-S50EC (d,d-transsifenotrin $50 \mathrm{~g} / \mathrm{l}$ ) terhadap Nyamuk Aedes aegypti dengan Metode Pengabutan (Thermal Fogging). Jurnal. Loka Litbang Kesehatan Pangandaran. PP 73-82. 


\section{At-Taqaddum}

Vol. 12 No. 1 (2020) 47-54

Rachman, Z. (2014). Faktor-Faktor Yang Berhubungan Dengan Kejadian Pediculosis capitis Pada Santri Pesantren Rhodlotul Quran Semarang. Skripsi. Semarang. Fakultas kedokteran Dipenogoro.

Rahayu, Y. S. E., Widyoningsih. (2016). Efektifitas Formulasi Ekstrak Sereh Wangi Dan Minyak Kelapa Murni Sebagai Pembasmi Kutu Rambut. STIKES Al-Irsyad AlIslamiyyah Cilacap. 